\title{
B(a)P adduct levels and fertility: A cross-sectional study in a Sicilian population
}

\author{
GEA OLIVERI CONTI $^{1}$, ALDO EUGENIO CALOGERO ${ }^{2}$, FILIPPO GIACONE ${ }^{2}$, MARIA FIORE ${ }^{1}$, \\ MARTINA BARCHITTA ${ }^{3}$, ANTONELLA AGODI ${ }^{3}$ and MARGHERITA FERRANTE ${ }^{1}$ \\ ${ }^{1}$ Environmental and Food Hygiene Laboratories, Department of Medical, Surgical Sciences and Advanced \\ Technologies 'G.F. Ingrassia'; Departments of ${ }^{2}$ Clinical and Experimental Medicine, and ${ }^{3}$ Medical, Surgical \\ Sciences and Advanced Technologies 'G.F. Ingrassia', University of Catania, I-95123 Catania, Italy
}

Received December 30, 2016; Accepted February 23, 2017

DOI: $10.3892 / \mathrm{mmr} .2017 .6396$

\begin{abstract}
Benzo(a)pyrene (BaP) is a carcinogenic polycyclic aromatic hydrocarbon for human tissues. Still today it is not fully investigated if BaP can affect negatively the male fertility through the BaP-DNA adducts production. In the present study, BaP Tetrol I-1 (TI-1) and BaP Tetrol II-2 (TII-2) BaP-DNA adducts were investigated in spermatozoa of a Sicilian male population. Semen samples from 86 volunteers in two eastern Sicilian cities (Regalbuto and Melilli) were collected. The quality of semen was evaluated in all samples according to the World Health Organization (WHO) guidelines. We analyzed BaP-DNA adducts in extracted sperm cell DNA using the modified high-performance liquid chromatography-fluorescence method to detects both Tetrols. Differences between Tetrol levels were assessed by the Wilcoxon signed-rank test and the Mann-Whitney U test, as appropriate. Correlation between semen quality parameters and Tetrol concentrations were analyzed using the Spearman's correlation coefficient. $\Sigma$ (TI-1+TII-2) were significantly higher in spermatozoa of volunteers from Regalbuto. Furthermore, a greater dispersion of the levels of adducts was observed in these specimens. TI-1 adducts were higher than TII-2 in Melilli samples (95\% CI) and TII-2 were higher than TI-1 in Regalbuto semen samples (95\% CI). A significant inverse correlation between sperm progressive motility and both TI-1 and TII-2 adducts was observed. The present study showed that BaP negatively affects male fertility by TI-1 and TII-2 DNA-adduct production. These results suggest that DNA adducts could be used as biomarker to assess $\mathrm{BaP}$ exposure by air pollution. Further studies are
\end{abstract}

Correspondence to: Professor Aldo Eugenio Calogero, Department of Clinical and Experimental Medicine, Surgical Sciences and Advanced Technologies 'G.F. Ingrassia', University of Catania, Via Santa Sofia 78, I-95123 Catania, Italy

E-mail: acaloger@unict.it

Key words: benzo(a)pyrene, male fertility, risk, sperm, toxicology, high-performance liquid chromatography, DNA, Italy, public health, andrology needed to confirm if these findings could affect male fertility because of the growing impairment of this function observed in recent years.

\section{Introduction}

Polycyclic aromatic hydrocarbons (PAHs) are considered a dangerous pollutant for human health due to their carcinogenic and mutagenic activity. PAHs are generated by the incomplete combustion of fossil fuels, tobacco smoke and grilled or broiled foods (1-3). Benzo(a)pyrene (BaP) is the most widely investigated PAH as a marker for the carcinogenic risk of PAHs in ambient air. BaP has been classified as carcinogenic to humans (4) and it can generate reactive oxygen species that may result in cell apoptosis $(5,6)$ and/or generalized inflammations in several tissues (7-10). Both $\mathrm{BaP}$ and its metabolites are known for their capacity of producing BP diol-epoxide-DNA adducts (BPDE). It is generally agreed that $( \pm)$-anti-BaPDE is the metabolite that forms the major adducts with DNA in vivo (11). BPDE adducts can interfere or alter DNA replication (12). Biomarkers are required to develop novel therapeutics and risk-assessment methodologies. In fact, BPDE adducts reflect individual variation of exposure, absorption, metabolic activation and DNA repair, also, there is no dose of exposure below which BPDE adducts are not produced. Therefore, they represent valuable environmental risk biomarkers (13). In particular, several authors have measured the anti-BPDE hydrolyzed DNA adducts or Tetrol I-1 (r-7,c-10t-8,t-9-tetrahydroxy-7,8,9,10-tetrahydrobenzo(a) pyrene) and syn-BPDE hydrolyzed DNA adducts or Tetrol II-2 (8r-7,t-9,t-10,t-8-tetrahydroxy-7,8,9,10-tetrahydrobenzo(a) pyrene) (11). Several studies report a correlation between BPDE adducts and various diseases, such as cancer (14) and behavioral outcomes in children $(15,16)$, whereas very few studies report altered fertility in male adults $(17,18)$. At present, male fertility represents a relevant worldwide issue. There are no exhaustive data for global prevalence of male infertility but, according to World Health Organization (WHO), nearly 60-80 million couples worldwide currently suffer from infertility (19). It varies across regions of the world and it is estimated to affect $8-12 \%$ of couples on average. According to a WHO's multicentric study, in $20 \%$ of cases the couple's 
infertility was attributed to male infertility, $38 \%$ to female infertility, $27 \%$ due to infertility of both partners, and $15 \%$ could not be attributed to either partner (20). Moreover, often no detectable cause can be associated to a male infertility by measuring the conventional parameters on sperm analysis. This is defined as unexplained or idiopathic infertility (20).

Few studies have investigated the association between BPDE adducts in DNA of human spermatozoa and male fertility $(12,17,18)$. Only two articles are available to date about the association between BPDE adduct numbers measured by immunofluorescence technique in sperm-extracted DNA and fertility, but these studies were carried out only in infertile men $(17,18)$. The immunofluorescence, immunostaining, COMET assay and ${ }^{23} \mathrm{P}$-postlabelling techniques are all used for BPDE adducts tests, but these techniques are not able to measure a single Tetrol or only BaP-adducts, thus providing a total generic PAH-DNA adduct concentration.

Therefore, the aim of the present study was to verify this hypothesis measuring the Tetrol I-1 and Tetrol II-2 in population's semen of eastern Sicily (Italy) by high-performance liquid chromatography-fluorescence (HPLC-FL) method. The present study is the first carried out on general population and that reported both Tetrol I-1 and Tetrol II-2 individually in human sperm.

\section{Materials and methods}

Sampling. Semen of 86 volunteers from Eastern Sicilian cities (from Regalbuto, a small town in a rural agricultural and Melilli a small town in an industrial district) (Fig. 1) was collected at Division of Andrology, University of Catania. Semen samples were collected after 3-5 days of abstinence and analyzed according to the WHO criteria (21). The volunteers joined the study by signing the informed consent and by filling out a semi-structured questionnaire. The questionnaire elicited anthropometric information, demographic, lifetime residential history (location of birth and duration of residence), history of active and passive smoking (including number of household members who smoke), date of smoking cessation, occupational exposure, medication information, and consumption of PAH-containing meat (frequency of eating fried, broiled, or barbecued meat, mineral or drink water during the last 2 weeks). Socioeconomic information related to income, education, hobbies and sports preferred was also collected.

Semen quality assessment. Sperm parameters (volume, sperm concentration, total sperm counts, progressive motility, and normal forms) were evaluated in all samples according to the WHO criteria (21).

DNA adducts analysis. We analyzed hydrolyzed BPDE adducts or Tetrol I-1 and Tetrol II-2 in extracted sperm cell DNA using the modified HPLC-FL method according to Alexandrov et al (22) modified. Briefly, the semen samples were collected at the Laboratory of the Division of Andrology and aliquoted, for semen quality parameter assessment and for molecular analysis. DNA was extracted using the DNA IQ ${ }^{\mathrm{TM}}$ system (Promega Corp., Madison, WI, USA) according to the manufacturer's instructions. Then, the DNA was subjected to a procedure of hydrolysis and purification.
Reagent. HPLC-grade water was produced in-house using a Milli- ${ }^{\circledR}$ system (Merck KGaA, Darmstadt, Germany). Methanol, ethyl acetate, ethanol, and acetonitrile, all LiChrosolv ${ }^{\circledR}$ hypergrade, were purchased from Sigma-Aldrich (Saint Louis, MO, USA).

Hydrochloric acid $(\mathrm{HCl})$ hypergrade and $\mathrm{NaOH}$ were purchased from Merck KGaA (Darmstadt, Germany).

Purification of acid. The $\mathrm{HCl}$, also if hypergrade, contains fluorescent impurities. One of which in particular, having the same retention time, interferes with Tetrol I-1, hence influencing the concentration of this hydrolyzed BaP-adduct. To eliminate this preparative bias all fluorescent impurities were deleted from $\mathrm{HCl}(0.4 \mathrm{~N})$ heating this for $4 \mathrm{~h}$ at $90^{\circ} \mathrm{C}$ and successively extracted three times with ethyl acetate.

Analytical procedures. A specialized laboratory was dedicated to the biochemical analysis as the detection of Tetrols is difficult. To avoid the fluorescent impurities contaminating samples, the vials, tips, tubes, syringes and capillaries for HPLC mobile phases and any other equipment used were washed with methanol hypergrade.

The extracted and purified DNA was dissolved in $1 \mathrm{ml}$ of water and analyzed in a Perkin Elmer Series 200 HPLC (Perkin-Elmer, Milano, Italy).

Preparation of samples was carried out through the following steps: i) hydrolysis of purified DNA diluted with purified $\mathrm{HCl}(0.4 \mathrm{~N})$ and then neutralized with $\mathrm{NaOH}(1 \mathrm{~N})$ to $\mathrm{pH} 7-7.5$; ii) the sample was then diluted $(20 \%)$ with methanol; iii) subsequently it was purified using Sep-Pak C18 (Waters Corp., Milford, MA, USA) cartridges SPE-equilibrated with $20 \%$ methanol drop by drop with a flow rate of $2.0 \mathrm{ml} / \mathrm{min}$ for $10 \mathrm{~min}$; iv) Tetrols I-1 and II-2 were eluted with $1 \mathrm{ml}$ of methanol (55\%). v) Samples were evaporated to dryness with a gentle stream of nitrogen and reconstituted with $100 \mu \mathrm{l}$ of methanol and of these, $30 \mu \mathrm{l}$ were injected into HPLC column.

Chromatographic settings and materials. Automated analysis was performed using an integrated system of Perkin Elmer coupled to Series 200 quaternary pump, peltier column, autosampler, UV detector, fluorescence detector and a degasser apparatus, all Series 200 (Perkin-Elmer). Chromatographic analysis was carried out in a Tosoh $(\mathrm{C} 18 \mathrm{RP} 25 \times 0.46 \mathrm{~cm}$, $5 \mu \mathrm{m}$ ) eluted with a elution program of 15 min with $20 \%$ water/acetonitrile of equilibrium phase, followed by $5 \mathrm{~min}$ with $20 \%$ water/acetonitrile and $60 \mathrm{~min}$ to acetonitrile (100\%) with a curve of 1 and finally other $10 \mathrm{~min}$ to $100 \%$ acetonitrile a flow rate of $0.85 \mathrm{ml} / \mathrm{min}$. The excitation wavelength was set at $344 \mathrm{~nm}$ and the fluorescence emission wavelength at $388 \mathrm{~nm}$. The sensitivity of the detector was fixed to high modality. The wavelength of UV detector was set at $238 \mathrm{~nm}$ for the double detection of both Tetrols. The chromatographic system was calibrated using Tetrol I-1 and Tetrol II-2 certified pure standards of $\mathrm{NCl}$ (Chemical Carcinogen Reference Standard Repository, Kansas City, MO, USA). Tetrol I-1 and Tetrol II-2 (purity 99.0\%; both from Sigma Aldrich) were used as external standards (Fig. 2). Recovery was 93\% and $81 \%$ for Tetrol I-1 and Tetrol II-2, respectively (Fig. 3). Processing of reagent blank disclosed no trace of Tetrol I-1 and Tetrol 


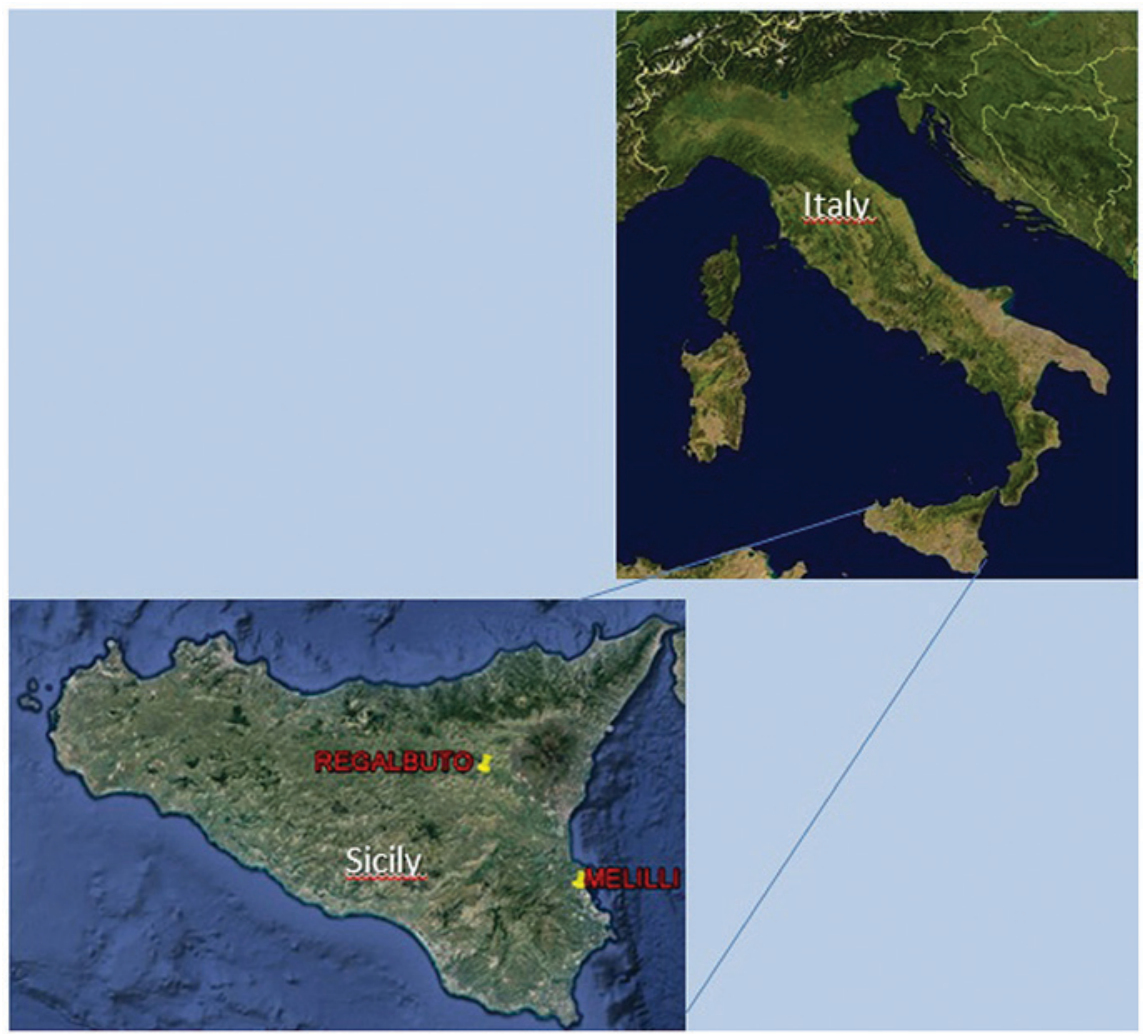

Figure 1. Map of the sampling locations.
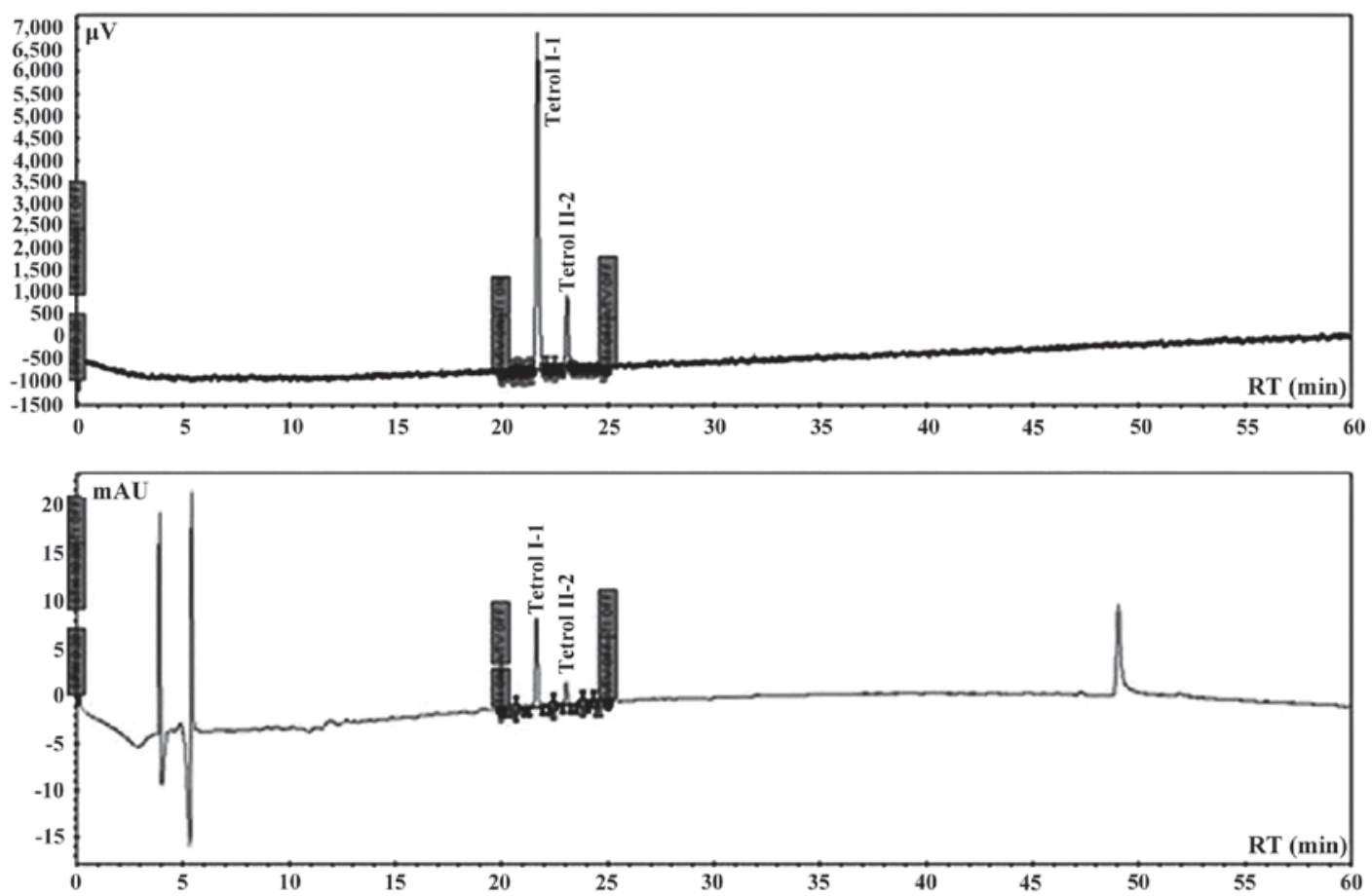

Figure 2. UV and fluorescence chromatograms of Tetrol standards.

II-2. Linearities $\left(\mathrm{R}^{2}\right)$ of calibrated chromatographic system were 0.9980 and 0.9854 for fluorescence and UV detectors, respectively for Tetrol I-1. For Tetrol II-2, the linearities were 0.9950 and 0.9943 for fluorescence and UV detectors, respectively. MDL were 2.0 and $3.1 \mathrm{pg} / \mathrm{ml}$ for Tetrol I-1 and Tetrol II-2, respectively. The HPLC software used for area integrations and linearity computing was TotalChrome (version 2010; Agilent Technologies, Santa Clara, CA, USA).

Statistical analysis. Statistical analysis was performed using SPSS version 21.0 (IBM SPSS, Armonk, NY, USA). P<0.05 was considered to be statistically significant. 


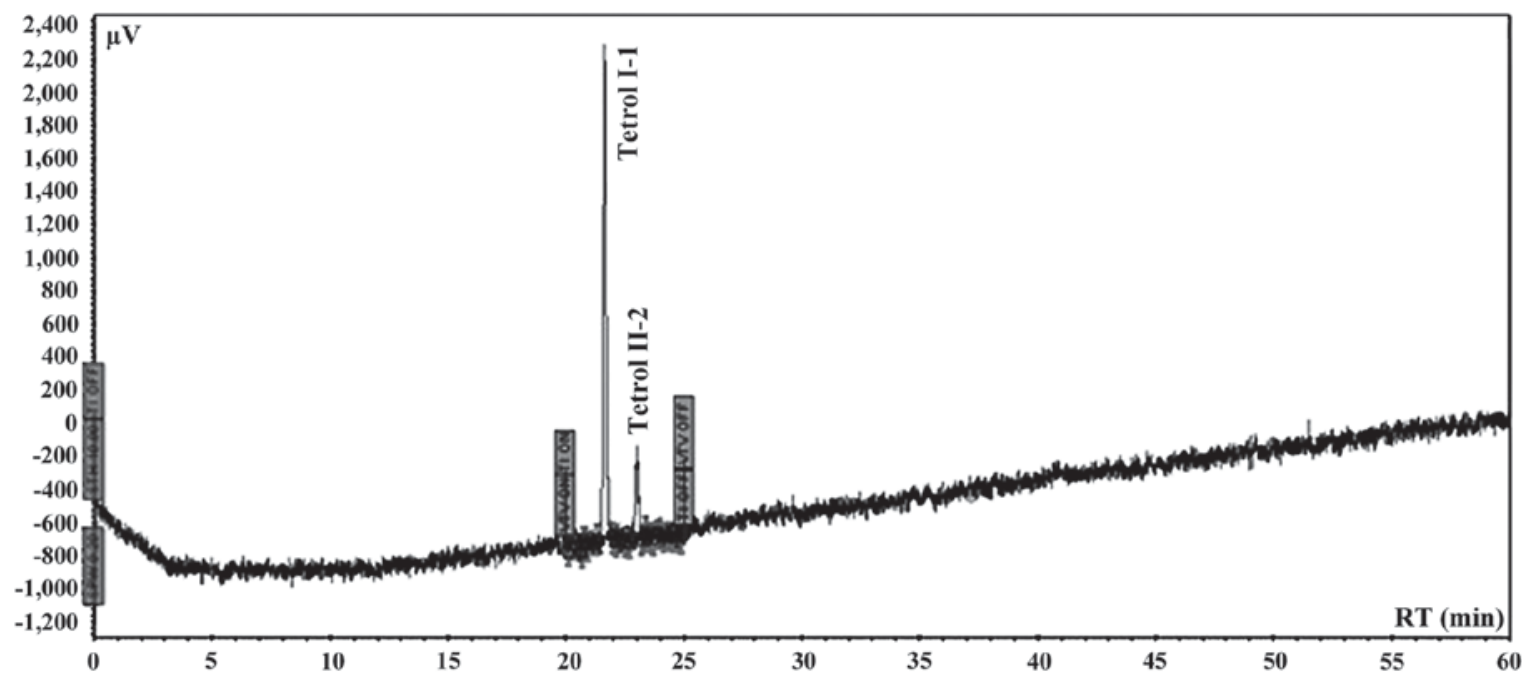

Figure 3. Fluorescence chromatogram of a spiked sample.

Table I. Distribution of conventional sperm parameters.

\begin{tabular}{lccccc}
\hline Variables & Min & 25th & Median & 75th & Max \\
\hline $\begin{array}{l}\text { Sperm concentration } \\
\text { (millions/ml) }\end{array}$ & 0.0 & 32.5 & 76.0 & 113.5 & 250.0 \\
$\begin{array}{l}\text { Total sperm count } \\
\text { (millions/ejaculate) }\end{array}$ & 0.0 & 95.6 & 204.0 & 350.0 & 825.0 \\
$\begin{array}{l}\text { Progressive } \\
\text { motility (\%) }\end{array}$ & 1.0 & 24.0 & 33.0 & 42.0 & 62.0 \\
\begin{tabular}{l} 
Normal forms (\%) \\
\hline
\end{tabular} & 8.0 & 13.0 & 16.0 & 20.0 & 33.0 \\
\hline
\end{tabular}

Table II. Distribution of Tetrol I-1 and Tetrol II-2 (n. Adduct $/ 10^{8}$ nucleotides).

\begin{tabular}{lccccr}
\hline Variables & Min & 25th & Median & 75th & \multicolumn{1}{c}{ Max } \\
\hline Tetrol I-1 & 0,00100 & 0,00240 & 0,00540 & 0,05226 & 103,58500 \\
Tetrol II-2 & 0,00200 & 0,00731 & 0,01712 & 0,17862 & 52,67400 \\
\hline
\end{tabular}

Descriptive analyses were performed using interquartile interval, min, max and $95 \%$ confidence intervals $(95 \% \mathrm{CI}$ ) for quantitative variables.

The differences between Tetrol levels were assessed by the Wilcoxon signed-rank test and the Mann-Whitney U test, as appropriate. Correlation analysis between sperm quality parameters and Tetrol levels was performed by Spearman's correlation coefficient $(\rho)$.

\section{Results}

The numbers of Tetrol adducts ( $\mathrm{n}$. adducts $/ 10^{8}$ nucleotides) detected in sperm samples are reported in Tables I and II.

Tetrol I-1 and Tetrol II-2 stratifications by residence (IC 95\%) are shown in Figs. 4 and 5. Table III shows the correlations between sperm parameters, age, cigarette/day and adducts Tetrol I-1 and Tetrol II-2. A significant inverse

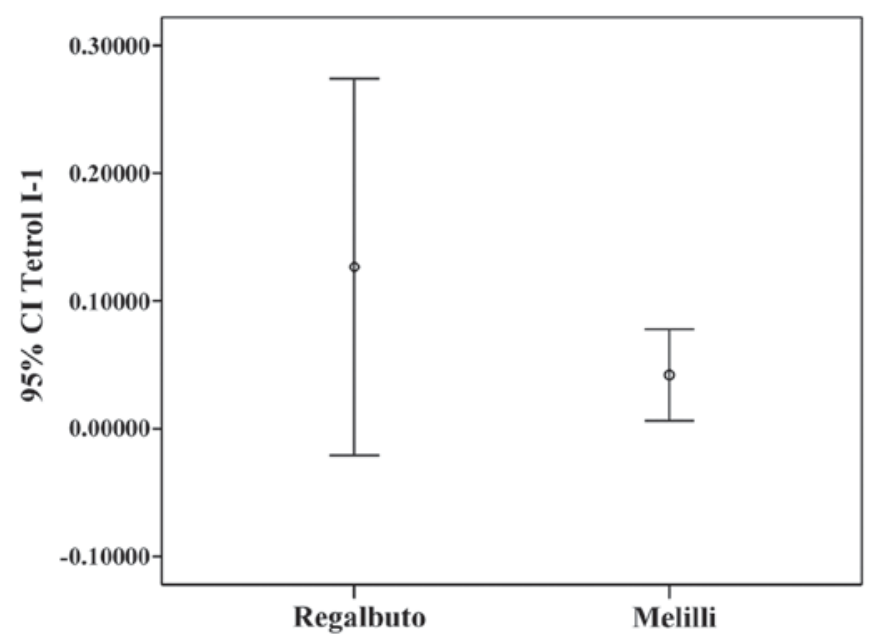

Figure 4. Tetrol I-1 confidence interval (IC 95\%) by area of residence.

correlation between sperm progressive motility and both TI-1 and TII-2 was observed (Table III).

\section{Discussion}

Male infertility is an alarming global health issue that has not been studied to truly understand its magnitude and prevalence. PAHs are a class of organic compounds produced by incomplete combustion or high-pressure processes $(23,24)$ that can affect human health. The present study investigated the hypothesis of an association between BPDE-DNA adducts in human sperms and fertility. The results of the present study showed that $\Sigma_{\text {(Tetrol I-1+Tetrol II-2) }}$ were significantly higher in the volunteers' semen from Regalbuto (a rural area) than in those of men living in an industrial area. Moreover, we found that Tetrol I-1 was higher than Tetrol II-2 in samples from Regalbuto, whereas Tetrol II-2 was higher than Tetrol I-1 in Melilli samples. Furthermore, a greater dispersion of adduct levels was observed in these specimens (Figs. 4 and 5). A significant inverse correlation was found between sperm progressive motility and the two Tetrols 
Table III. Correlation between conventional parameters and Tetrols.

\begin{tabular}{|c|c|c|c|c|c|c|c|c|c|c|}
\hline & & $\begin{array}{c}\text { Tetrol } \\
\text { I-1 }\end{array}$ & $\begin{array}{c}\text { Tetrol } \\
\text { II-2 }\end{array}$ & $\begin{array}{c}\text { Sperm } \\
\text { concentration }\end{array}$ & $\begin{array}{c}\text { Progressive } \\
\text { motility }\end{array}$ & MNP c & $\begin{array}{l}\text { Normal } \\
\text { forms }\end{array}$ & $\begin{array}{l}\text { Total } \\
\text { count }\end{array}$ & Age & $\begin{array}{c}\text { Cigarette/ } \\
\text { day }\end{array}$ \\
\hline \multirow[t]{3}{*}{ Tetrol I-1 } & $\mathrm{R}$ & 1.000 & & & & & & & & \\
\hline & $\mathrm{P}$ & . & & & & & & & & \\
\hline & $\mathrm{N}$ & 86 & & & & & & & & \\
\hline \multirow[t]{3}{*}{ Tetrol II-2 } & $\mathrm{R}$ & $0.869^{\mathrm{b}}$ & 1.000 & & & & & & & \\
\hline & $\mathrm{P}$ & 0.000 & . & & & & & & & \\
\hline & $\mathrm{N}$ & 86 & 86 & & & & & & & \\
\hline \multirow[t]{3}{*}{ Sperm concentration } & $\mathrm{R}$ & 0.077 & 0.022 & 1.000 & & & & & & \\
\hline & $\mathrm{P}$ & 0.480 & 0.840 & . & & & & & & \\
\hline & $\mathrm{N}$ & 86 & 86 & 86 & & & & & & \\
\hline \multirow[t]{3}{*}{ Progressive motility } & $\mathrm{R}$ & $-0.264^{\mathrm{a}}$ & $-0.222^{\mathrm{a}}$ & 0.052 & 1.000 & & & & & \\
\hline & $\mathrm{P}$ & 0.014 & 0.040 & 0.502 & . & & & & & \\
\hline & $\mathrm{N}$ & 86 & 86 & 86 & 86 & & & & & \\
\hline \multirow[t]{3}{*}{ MNP c } & $\mathrm{R}$ & $0.234^{\mathrm{a}}$ & $0.279^{\mathrm{b}}$ & 0.025 & $-0.606^{b}$ & 1.000 & & & & \\
\hline & $\mathrm{P}$ & 0.030 & 0.009 & 0.750 & 0.000 & . & & & & \\
\hline & $\mathrm{N}$ & 86 & 86 & 86 & 86 & 86 & & & & \\
\hline \multirow[t]{3}{*}{ Normal forms } & $\mathrm{R}$ & 0.137 & 0.201 & 0.123 & $0.161^{\mathrm{a}}$ & -0.015 & 1.000 & & & \\
\hline & $\mathrm{P}$ & 0.209 & 0.063 & 0.109 & 0.035 & 0.848 & . & & & \\
\hline & $\mathrm{N}$ & 86 & 86 & 86 & 86 & 86 & 86 & & & \\
\hline \multirow[t]{3}{*}{ Total count } & $\mathrm{R}$ & 0.061 & 0.042 & $0.820^{\mathrm{b}}$ & 0.143 & -0.013 & $0.228^{\mathrm{b}}$ & 1.000 & & \\
\hline & $\mathrm{P}$ & 0.579 & 0.702 & 0.000 & 0.063 & 0.866 & 0.003 & . & & \\
\hline & $\mathrm{N}$ & 86 & 86 & 86 & 86 & 86 & 86 & 86 & & \\
\hline \multirow[t]{3}{*}{ Age } & $\mathrm{R}$ & -0.152 & $-0.225^{\mathrm{a}}$ & -0.006 & 0.041 & -0.060 & 0.021 & 0.056 & 1.000 & \\
\hline & $\mathrm{P}$ & 0.165 & 0.038 & 0.941 & 0.595 & 0.440 & 0.786 & 0.465 & . & \\
\hline & $\mathrm{N}$ & 85 & 85 & 86 & 86 & 86 & 86 & 86 & 86 & \\
\hline \multirow[t]{3}{*}{ Cigarette/day } & $\mathrm{R}$ & 0.101 & 0.191 & 0.015 & 0.028 & 0.126 & $0.253^{\mathrm{a}}$ & 0.143 & $0.358^{\mathrm{b}}$ & 1.000 \\
\hline & $\mathrm{P}$ & 0.575 & 0.286 & 0.903 & 0.823 & 0.312 & 0.040 & 0.248 & 0.002 & . \\
\hline & $\mathrm{N}$ & 40 & 40 & 40 & 40 & 40 & 40 & 40 & 40 & 40 \\
\hline
\end{tabular}

${ }^{\mathrm{a} C}$ Correlation is significant at the 0.05 level (two-tailed). ${ }^{\mathrm{b}}$ Correlation is significant at the 0.01 level (two-tailed). R, Spearman's rank correlation; $\mathrm{P}, \mathrm{P}$-value; $\mathrm{N}$, number of men.

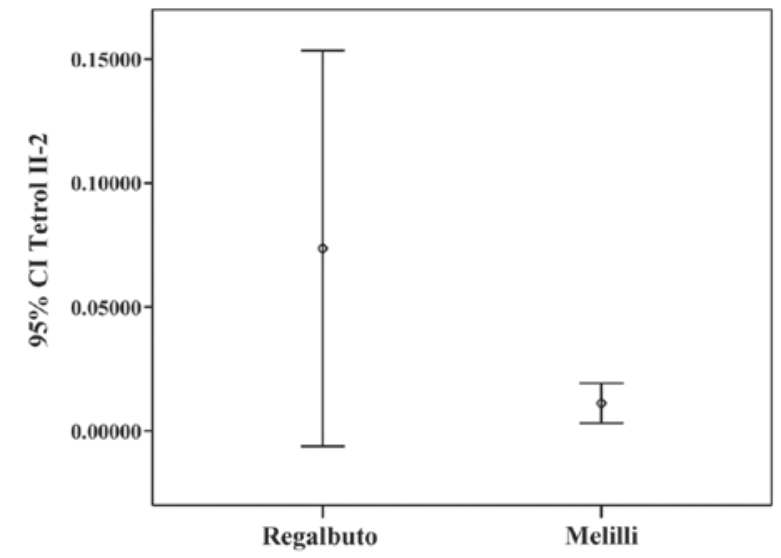

Figure 5. Tetrol II-2 confidence interval (IC 95\%) by area of residence.

(Table III). Furthermore, no correlation was found between smoking and BPDE-DNA adducts. In fact, the non-smokers
(46 subjects) showed median value of Tetrols higher than smokers (40 subjects) (Tetrol I-1: 0.00540 vs. 0.00375; Tetrol II-2: 0.01618 vs. 0.01605$)$.

The present study showed that BaP negatively affects sperm parameters by BPDE-DNA adducts production. Few studies $(12,17,18)$ have found that increased levels of DNA adducts in humans are associated with sperm motility and impaired male fertility, but up to now there are inconsistencies in the evidence for a link with smoking $(17,25-27)$ except for the lung tissue. In fact, the relationship between smoking-related DNA adducts must be considered on a tissue-by-tissue basis (25). In a similar Italian study, Gaspari et al (17) showed that PAH-DNA adducts, measured as sum by immunofluorescence analysis, were negatively correlated with the percentage of spermatozoa with normal morphology and neck morphological abnormalities, whereas a positive correlation was found with head abnormalities. Furthermore, these authors reported a significantly association between occupational exposure to $\mathrm{PAH}$ and PAH-DNA adducts in spermatozoa and none significantly 
association between smoking and sperm PAH-DNA adducts. Lastly, a higher number of PAH-DNA adducts was found in infertile patients vs. fertile men. A weak association between tobacco consumption and BPDE-DNA adducts (measured with immunofluorescence technique) in spermatozoa of professional exposed infertile men was reported (18). However, several authors reported that BaP-DNA adducts were associated significantly with environmental $\mathrm{BaP}$ exposure and in particular to air BaP pollution $(1,28)$.

The presence of a major adducts dispersion and concentration in men from Regalbuto is a very original and interesting finding. No data are available about male population fertility or environment pollution of Regalbuto until today. Our hypothesis is that the residents of this town are exposed to air pollution due to archaic agricultural practices such as the controlled fires of fields (fires are high natural BaP source of emission in atmosphere). This is a usual practice in this geographical area and no control or monitoring is applied to verify the pollution produced. This hypothesis is supported by some available data on the topic (29).

In contrast, the residents of Melilli are also exposed to air pollution but, being a city with an industrial pole devoted to oil refining and energy and chemical production, this is a very controlled area through a network of fixed stations for the control of atmospheric pollution. This continued monitoring allows an appropriate management of the production cycle to prevent the increasing air pollution.

No data are available today on the relationship between smoked foods consume and BaP-DNA adducts in spermatozoa but, for other tissue, Tang et al (13) reported that dietary PAHs do not significantly contribute to adducts number (13). No data are available on the different number of Tetrol I-1 and Tetrol II-2, for this reason the present study added very original data to the scientific literature. Indeed, the higher number of Tetrol II-2 compared to Tetrol I-1 can be explained through some molecular mechanisms, such as a higher susceptibility of one chain of DNA vs. genotoxic effects of BaP or, inefficiency of some enzymes for DNA repair (30-32). In particular, there is available evidence about the XRCC1 polymorphisms that may modify sperm PAH-DNA adduct levels (32). Thus, this highly sensitive and specific procedure is suitable for measuring BPDE-DNA adducts in human spermatozoa from environmentally exposed subjects and it could be adapted to measure PAH effects in genital organs.

Despite the considerable interest raised regarding the air pollution for the multiple adverse effects reported on human health from inflammation to cancer, its impact on fertility remains still unclear $(33,34)$. A significant impact of air pollution on miscarriage and clinical pregnancy rates in the general population was reported. Furthermore, some air contaminants seem to negatively impact on fertility outcomes, including miscarriage and live birth rates, in subfertile patients $(33,34)$.

In conclusion, the present study, for first time, investigated the hypothesis of an association between BaP-DNA adducts and human male infertility. The results seem to indicate that this hypothesis may be real and very interesting data were found including a new molecular strategy to study male infertility. Because spermatozoa are not the target cells for $\mathrm{BaP}$ exposure, the relationship between PAH-DNA adducts and these germinal cells remain to be determined.

\section{References}

1. Guerreiro CBB, Horálek J, de Leeuw F and Couvidat F: Benzo(a) pyrene in Europe: Ambient air concentrations, population exposure and health effects. Environ Pollut 214: 657-667, 2016.

2. Sciacca $S$ and Oliveri Conti G: Mutagens and carcinogens in drinking water. Med J Nutrition Metab 2: 157-162, 2009.

3. Conte F, Copat C,Longo S, Conti G, Grasso A, Arena G,Dimartino A, Brundo MV and Ferrante M: Polycyclic aromatic hydrocarbons in Haliotis tuberculata (Linnaeus, 1758) (Mollusca, Gastropoda): Considerations on food safety and source investigation. Food Chem Toxicol 94: 57-63, 2016.

4. International Agency for Research on Cancer (IARC): Chemical Agents and Related Occupations. IARC Monographs, Vol. 100 F. International Agency for Research on Cancer, Lyon, 2012.

5. Liou GY and Storz P: Reactive oxygen species in cancer. Free Radic Res 44: 479-496, 2010.

6. Ferecatu I, Borot MC, Bossard C,Leroux M, Boggetto N, Marano F, Baeza-Squiban A and Andreau K. Polycyclic aromatic hydrocarbon components contribute to the mitochondria-antiapoptotic effect of fine particulate matter on human bronchial epithelial cells via the aryl hydrocarbon receptor. Part Fibre Toxicol 21: (7) 18, 2010.

7. Signorelli SS, Anzaldi M, Libra M, Navolanic PM, Malaponte G, Mangano K, Quattrocchi C, Di Marco R, Fiore V and Neri S: Plasma levels of inflammatory biomarkers in peripheral arterial disease: Results of a cohort study. Angiology 67: 870-874, 2016.

8. Yang L, Liu G, Lin Z, Wang Y, He H, Liu T and Kamp DW: Pro-inflammatory response and oxidative stress induced by specific components in ambient particulate matter in human bronchial epithelial cells. Environ Toxicol 31: 923-936, 2016.

9. Signorelli SS, Fatuzzo P, Rapisarda F, Neri S, Ferrante M, Oliveri Conti G, Fallico R, Di Pino L, Pennisi G, Celotta G, et al: A randomised, controlled clinical trial evaluating changes in therapeutic efficacy and oxidative parameters after treatment with propionyl L-carnitine in patients with peripheral arterial disease requiring haemodialysis. Drugs Aging 23: 263-270, 2006.

10. Signorelli SS, Fatuzzo P, Rapisarda F, Neri S, Ferrante M, Oliveri Conti G, Fallico R, Di Pino L, Pennisi G, Celotta G, et al: Propionyl-L-carnitine therapy: Effects on endothelin-1 and homocysteine levels in patients with peripheral arterial disease and end-stage renal disease. Kidney Blood Press Res 29: 100-107, 2006.

11. Alexandrov K, Sala M and Rojas M: Differences in the DNA adducts formed in cultured rabbit and rat dermal fibroblasts by benzo(a)pyrene and (-)benzo(a)pyrene-7,8-diol. Cancer Res 48: 7132-7139, 1988

12. U.S. Environmental Protection Agency (EPA): Toxicity and Exposure Assessment for Children's Health (TEACH). https:// archive.epa.gov/region5/teach/web/html/index.html. Accessed January 10, 2017.

13. Tang D, Li T, Liu JJ, Chen J, Qu L, Perera F: PAH-DNA adducts in cord blood and fetal and child development in a Chinese cohort. Environ Health Perspect 114: 1297-1300, 2006.

14. United States Environmental Protection Agency (U.S. EPA): IRIS Toxicological Review of Benzo[a]pyrene (Final Report). U.S. Environmental Protection Agency, Washington, DC, EPA/635/R17/003F, 2017. https://cfpub.epa.gov/si/si_public_record_report. cfm?dirEntryId=329750.

15. Perera FP, Chang HW, Tang D, Roen EL, Herbstman J, Margolis A, Huang TJ, Miller RL, Wang S and Rauh V: Early-life exposure to polycyclic aromatic hydrocarbons and ADHD behavior problems. PLoS One 5: e111670, 2014.

16. Perera FP, Tang D, Wang S, Vishnevetsky J, Zhang B, Diaz D, Camann D and Rauh V: Prenatal polycyclic aromatic hydrocarbon $(\mathrm{PAH})$ exposure and child behavior at age 6-7 years. Environ Health Perspect 120: 921-926, 2012.

17. Gaspari L, Chang SS, Santella RM, Garte S, Pedotti P and Taioli E: Polycyclic aromatic hydrocarbon-DNA adducts in human sperm as a marker of DNA damage and infertility. Mutat Res 535: 155-160, 2003.

18. Zenzes MT, Bielecki R and Reed TE: Detection of benzo(a) pyrene diol epoxide-DNA adducts in sperm of men exposed to cigarette smoke. Fertil Steril 72: 330-335, 1999.

19. Rutstein SO and Shah IH: Infecundity, infertility, and childlessness in developing countries. DHS Comparative Reports No 9. ORC Macro and the World Health Organization, Calverton, MD, 2004. 
20. Kumar N and Singh AK: Trends of male factor infertility, an important cause of infertility: A review of literature. J Hum Reprod Sci 8: 191-196, 2015.

21. World Health Organization (WHO): WHO Laboratory Manual for the Examination and Processing of Human Semen. 5th edition. WHO Press, Geneva, pp1-271, 2010.

22. Alexandrov K, Rojas M, Geneste O, Castegnaro M, Camus AM, Petruzzelli S, Giuntini C and Bartsch H: An improved fluorometric assay for dosimetry of benzo(a)pyrene diol-epoxide-DNA adducts in smokers' lung: Comparisons with total bulky adducts and aryl hydrocarbon hydroxylase activity. Cancer Res 52: 6248-6253, 1992.

23. Hayakawa K: Environmental behaviors and toxicities of polycyclic aromatic hydrocarbons and nitropolycyclic aromatic hydrocarbons. Chem Pharm Bull (Tokyo) 64: 83-94, 2016.

24. Conti GO, Copat C, Ledda C, Fiore M, Fallico R, Sciacca S and Ferrante M: Evaluation of heavy metals and polycyclic aromatic hydrocarbons (PAHs) in Mullus barbatus from Sicily channel and risk-based consumption limits. Bull Environ Contam Toxicol 88: 946-950, 2012.

25. Phillips DH and Venitt S: DNA and protein adducts in human tissues resulting from exposure to tobacco smoke. Int J Cancer 131: 2733-2753, 2012.

26. Gilberson T, Peluso ME, Munia A, Luján-Barroso L, Sánchez MJ, Navarro C, Amiano P, Barricarte A, Quirós JR, Molina-Montes E, et al: Aromatic adducts and lung cancer risk in the European Prospective Investigation into Cancer and Nutrition (EPIC) Spanish cohort. Carcinogenesis 35: 2047-2054, 2014.

27. Palli D, Saieva C, Munnia A, Peluso M, Grechi D, Zanna I, Caini S Decarli A, Sera F and Masala G: DNA adducts and PM(10) exposure in traffic-exposed workers and urban residents from the EPIC-Florence City study. Sci Total Environ 403: 105-112, 2008.
28. Jayachandran S: Air quality and early-life mortality: Evidence from Indonesia's wildfires. J Hum Resour 44: 916-954, 2009.

29. Oliveri Conti G, Heibati B, Kloog I, Fiore M and Ferrante M: A review of AirQ Models and their applications for forecasting the air pollution health outcomes. Environ Sci Pollut Res Int: Jan 4, 2017 (Epub ahead of print)

30. Miri M,Derakhshan Z, Allahabadi A,Ahmadi E, Oliveri Conti G, Ferrante $\mathrm{M}$ and Aval HE: Mortality and morbidity due to exposure to outdoor air pollution in Mashhad metropolis, Iran. The AirQ model approach. Environ Res 151: 451-457, 2016.

31. Ghanbari Ghozikali M, Heibati B, Naddafi K, Kloog I, Oliveri Conti G, Polosa R and Ferrante M: Evaluation of Chronic Obstructive Pulmonary Disease (COPD) attributed to atmospheric $\mathrm{O}_{3}, \mathrm{NO}_{2}$, and $\mathrm{SO}_{2}$ using Air Q Model (2011-2012 year). Environ Res 144: 99-105, 2016.

32. Wang Y, Kloog I, Coull BA, Kosheleva A, Zanobetti A and Schwartz JD: Estimating causal effects of long-term PM2.5 exposure on mortality in New Jersey. Environ Health Perspect 124: $1182-1188,2016$

33. Nieuwenhuijsen MJ, Basagaña X, Dadvand $P$, Martinez D, Cirach M, Beelen R and Jacquemin B: Air pollution and human fertility rates. Environ Int 70: 9-14, 2014.

34. Frutos V, González-Comadrán M, Solà I, Jacquemin B, Carreras R and Checa Vizcaíno MA: Impact of air pollution on fertility: A systematic review. Gynecol Endocrinol 31: 7-13, 2015. 